\title{
Kebijakan Larangan Pembangunan Ritel MOdERn DAN PEMBERdayaAn PEDAgang Kecil di BANYUWANGi
}

jurnal.kemendagri.go.id/index.php/ $\mathrm{mp}$

\section{e-ISSN: 2549-5283}

p-ISSN: 2549-5151

Matra Pembaruan 4 (2) (2020): 109118

DOI:-

10.21787/mp.4.2.2020.109-118

Keywords: Policy; Empowerment; Modern Ritail; Small Traders

Kata Kunci: Kebijakan; Pemberdayaan; Ritel Modern; Pedagang Kecil

\section{${ }^{*}$ Korespondensi \\ Phone : +6282165706050 \\ Email : wl.rosailiw@gmail. \\ com}

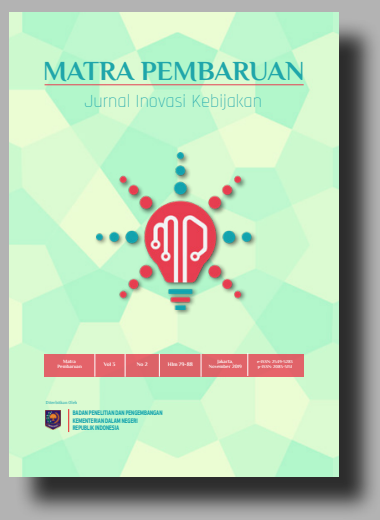

BADAN PENELITIAN DAN PENGEMBANGAN (BPP) KEMENTERIAN DALAM NEGERI

Jl. Kramat Raya No 132, Jakarta Pusat, 10450

(C)2020 Wilda Rasaili

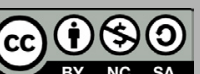

Karya ini dilisensikan di bawah Lisensi Internasional Creative Commons Atribusi Nonkomersial Sharealike 4.0.

\author{
Wilda Rasaili* \\ Universitas Wiraraja Madura \\ Jl. Raya Sumenep-Pamekasan KM. 05 Patean, Kabupaten Sumenep, \\ Jawa Timu
}

Dikirim: 18 Juni 2020; Direvisi: 5 November 2020;

Disetujui: 11 November 2020

\begin{abstract}
The government's strategy in minimizing the modern first time implemented by the banyuwangi regency government by a prohibiting policy of building modern retails. this policy is concidered unpopular because impedes invesment and regional income. This study aims to explain about the local government policy in minimizing the modern market and its implication for empowerment small traders. The theory used in this study is public policy and community empowerment with discriptive-explanatory research methods. The result in this study indicate the prohibition of development policies modern retails as strategy of local government to empower small traders. This policy has real impact on improving the economy and reducing the poverty rate significantly.
\end{abstract}

\section{Intisari}

Strategi pemerintah dalam mempersempit ruang pasar modern pertama kali diimplementasikan oleh pemerintah Kabupaten Banyuwangi melalui kebijakan larangan pembangunan ritel modern. Kebijakan ini dianggap tidak populer karena menghambat investasi dan pendapatan daerah. Penelitian ini bertujuan untuk menjelaskan kebijakan pemerintah daerah dalam mempersempit pasar modern dan implikasinya pada pemberdayaan pedagang kecil. Teori yang digunakan dalam kajian ini adalah kebijakan publik dan pemberdayaan masyarakat dengan metode penelitian deskriptif-eksplanatif. Hasil dari penelitian ini menunjukkan bahwa kebijakan larangan pembangunan mal dan ritel modern sebagai strategi pemerintahan daerah untuk memperdayakan pedagang kecil berdampak nyata pada peningkatan ekonomi dan mengurangi angka kemiskinan secara signifikan.

\section{Pendahuluan}

Selama beberapa dekade terakhir, ritel modern muncul sebagai aspek penting dalam ruang lingkup global. Istilah globalization of retailing mencakup perkembangan yang saling terkait, seperti; (1) pengecer telah berkembang membangun kehadiran pasar di negara-negara sesuai dengan perkembangan sistem ekonomi, (2) rantai pasokan yang mendasari operasional pengecer menjadi semakin dalam dilingkup global, dan (3) difusi inovasi ritel di berbagai belahan dunia (Reinarts, 2011, p.54). Pesatnya pertumbuhan ritel modern telah menjadi keniscayaan yang muncul di berbagai negara.

Di kawasan Eropa, ritel modern atau supermarket telah mengalami transformasi yang signifikan dan terus berpotensi besar melakukan perubahan-perubahan dalam mengeja tantangan, bahkan termasuk juga produsen-produsen makan, 
perusahaan pengelolaan dan distribusi berpotensi berkembang besar (Reardon, 2002, p. 371-388). Kemudian di Korea, pembangunan ritel modern atau bisnis distribusi juga cukup berkembang pesat, bahkan telah mempengaruhi pola konsumen yang lebih memilih belanja di department store dengan kenyamanan fasilitas, layanan yang ramah serta diskon-diskon besar. Pertumbuhan laju itu telah menurunkan jumlah pasar tradisional dari 1.660 di tahun 2005 menjadi 1.372 pada tahun 2013 (Heung-Ryel, 2015).

Di kawasan Asia, industri ritel juga berkembang sangat pesat serta memiliki semangat baru bagi perkembangan industri di Indonesia. Asosasi Pengecer Indonesia (APRIN-Do) mengklaim bahwa sektor ritel telah menciptakan pekerjaan tertinggi kedua. Terdapat sekitar 18,9 juta karyawan yang bekerja di sektor ritel modern. Kemudian jumlah ritel modern selama 5 tahun sejak tahun 2007 hingga 2011 mengalami pertumbuhan yang signifikan, yaitu sebesar $17,57 \%$ per tahun. Pada tahun 2007 sudah tercatat sebanyak 10.365 dan meningkat pada tahun 2011 menjadi 18.152 (Susilowati, 2014, p. 40). Angka pertumbuhan ritel modern dipengaruhi oleh daya konsumsi masyarakat, pertumbuhan jumlah penduduk, dan daya beli masyarakat. Pada dasarnya, pertumbuhan ritel modern ditujukan kepada masyarakat kelas menengah dan atas. Sebab, masyarakat modern ketika berbelanja cenderung tidak suka berdesakdesakan seperti di pasar tradisional (Soliha, 2008, p. 128).

Pertumbuhan ritel modern yang semakin pesat tentu tidak terlepas dari pengamatan akademis. Salah satu pihak menganggap bahwa ritel modern dapat mendorong laju ekonomi negara dengan pesat seperti pada peningkatan Produk Domistik Regional Bruto (PDRB) (Haryotejo, 2014). Tetapi pendapat lain juga muncul bahwa ritel modern dapat menurunkan pendapatan masyarakat lokal yang menjalankan bisnisnya (Triawan, 2018). Meski terjadi polemik, pertumbuhan ritel modern tidak dapat dibendung, karena sering kali pemerintah mengobral izin. Salah satu akibat dari hadirnya ritel modern dengan berbagai formatnya seperti supermarket dan minimarket dapat membunuh ritel tradisional (Soliha, 2008, p. 128).

Terlepas dari implikasi negatifnya terhadap pasar tradisional, investasi ritel modern memiliki manfaat bagi pemerintah daerah. Sebuah penelitian yang dilakukan oleh Setyorini di Kabupaten Bangil ditemukan bahwa melalui kebijakan pengaturan toko modern yang awalnya dianggap sebagai momok menakutkan bagi pasar tradisional ternyata dengan penataan yang dilakukan oleh Pemkab tidak berdampak buruk bagi pasar tradisional (Setyorini, 2013, pp. 7-20). Dalam penelitian tersebut disebutkan bahwa munculnya ritel modern dapat menambah retribusi daerah serta memudahkan masyarakat dalam bertransaksi.

Terlepas dari dampak positifnya, ada beberapa pemerintah daerah yang berkomitmen untuk membatasi izin pembangunan ritel modern. Salah satunya Pemerintah Kabupaten Banyuwangi melarang pembangunan mal dan ritel modern di daerah yang menyandang julukan The Sunrise ofJawa itu. Sebuah kebijakan yang tidak populer diambil oleh pemerintah daerah mengingat pembangunan mal dan ritel modern dalam suatu daerah dapat meningkatkan laju investasi dan perekonomian serta laju perkembangan investasi modern yang sulit dibendung di era globalisasi. Namun, geliat toko modern di era global serta pertimbangan retribusi daerah justru tidak mendapat ruang di Kabupaten Banyuwangi. Bahkan, Azwar Anas sebagai orang nomor satu di Banyuwangi mengharamkan adanya Indomart dan Alfamart di kabupaten yang terletak di ujung paling Timur pulau Jawa ini. Pemkab setempat juga mengatur dengan ketat jam operasional toko modern yang terlanjur mendapat izin dari pemerintah sebelumnya.

Kebijakan Pemkab Banyuwangi mengenai larangan pembangunan ritel modern mendapat respons dari berbagai pihak. Salah satunya tanggapan keras hadir dari Ketua Umum Asosiasi Pengelolaan Pusat Belanja Indonesia (APPBI), Stefanus Ridwan. Stefanus menganggap bahwa Bupati Banyuwangi perlu pencerahan dalam mengelola sistem ekonomi daerah. Menurutnya, bukan alasan rasional jika untuk melindungi pedagang kecil lalu melarang pembangunan ritel modern, justru pedagang kecil mendapatkan manfaat disekitar pusat perbelanjaan. Dalam pandangan Stefanus, pembangunan mal di suatu daerah tidak membunuh laju perekonomian, justru pembangunan tersebut dapat meningkatkan pertumbuhan ekonomi daerah. Keberadaan mal di daerah dapat mendorong geliat bisnis baru seperti pembangunan indekos, penyerapan tenaga kerja dan lahan pekerjaan lain (detik.com, 2012).

Berdasarkan penjelasan di atas menarik untuk dibahas dan dijelaskan mengapa Pemerintah Kabupaten Banyuwangi mengambil kebijakan pelarangan pembangunan mal dan ritel modern? Dalam analisis kebijakan publik erat kaitannya dengan pemberdayaan masyarakat, sehingga dalam kajian ini menguraikan secara rinci mengenai pemberdayaan ekonomi masyarakat kecil di Kabupaten Banyuwangi melalui kebijakan pelarangan dan penertiban sistem pasar dengan memperketat pendirian ritel modern.

Dalam penelusuran kepustakaan, penelitianpenelitian yang menjelaskan tentang kebijakan yang melarang pembangunan mal dan ritel modern untuk memperdayakan pedagang kecil di suatu daerah belum ada yang melakukan. Pada umumnya, beberapa penelitian terklasifikasi dalam 
tiga hal, yaitu: pertama, kebijakan pemerintah dalam menata ulang pasar tradisional untuk dapat bersaing dengan toko modern. Kedua, penelitian yang menjelaskan dampak keberadaan toko modern terhadap pasar tradisional. Ketiga, penelitian yang hampir mendekati yaitu kebijakan pemerintah menata, membina dan mengelola pasar, baik tradisional maupun modern. Dengan alasan tersebut, penulis tertarik untuk meneliti tentang kebijakan larangan pemerintah daerah Kabupaten Banyuwangi dan orientasinya pada pemberdayaan pedangan kecil.

Berangkat dari realitas di atas, untuk mendapat kajian yang mendalam dan detail, maka kebijakan publik dan pemberdayaan masyarakat dijadikan sebagai kerangka teori dalam kajian ini. Kebijakan publik sendiri didefinisikan sebagai arah tindakan yang dilakukan oleh pemerintah dengan tujuan untuk mengatasi suatu masalah yang ada (Winarno, 2007, p. 18). Menurut Nogroho, kebijakan publik merupakan konsep dan tindakan yang berhubungan dengan sistem pemerintahan untuk memenuhi kepentingan-kepentingan publik (Nugroho, 2014, p. 82). Sedangkan Anderson menggambarkan bahwa kebijakan publik merupakan pengambilan keputusan oleh pemerintah, kemudian melahirkan suatu tindakan untuk memecahkan masalah sosial dengan mengadopsi strategi yang spesifik dalam proses perencanaan dan mengimplementasikan ke ruang sosial (Osman, 2002, p. 37). Berdasarkan dua pandangan tokoh tersebut, dapat dipahami bahwa kebijakan publik adalah langkah-langkah yang dipilih oleh pemerintah untuk memenuhi kepentingan publik.

Peda perkembangannya, kebijakan publik lebih ditujukan kepada proses, yaitu pembuat kebijakan digambarkan sebagai sebuah proses bukan sebagai tindakan tunggal. Dalam sebuah proses setidaknya melibatkan negosiasi, tawarmenawar dan akomodasi (Osman, 2002, p. 37). Jika kebijakan publik lebih mengedepankan peran publik-pemerintah bukan sebagai pelaku tunggal-maka kebijakan akan lebih berpihak pada kepentingan-kepentingan publik. Kebijakan publik supaya tidak sekedar menguntungkan pemerintah, tapi juga dapat berimplikasi terhadap masyarakat, maka berbagai aktor harus dilibatkan dalam proses pengkajian, perumusan, dan penerapannya di masyarakat.

Kebijakan publik juga dilandaskan pada pilihan rasional. Kebijakan publik sebagian besar positif atau normatif, yaitu kebijakan yang tidak mengindikasikan kepentingan lain kecuali kepentingan sosial. Kepentingan sosial ini diartikan sebagai upaya untuk memperbaiki tatanan sosial, termasuk ekonomi masyarakat. Dengan demikian, kebijakan publik layaknya memudahkan masyarakat untuk menjalankan aktivitas kehidupannya (Toma,
2014, pp. 892-897). Jika rumusan kebijakan publik berkaitan dengan kelangsungan ekonomi, maka kebijakan itu idealnya mengedepankan kepentingan masyarakat secara umum, sehingga masyarakat dapat berinteraksi dalam dinamika ekonomi dan pasar.

Selain itu, kebijakan publik harus lahir beriringan dengan pemberdayaan masyarakat. Pemberdayaan di sini merupakan suatu proses peningkatan kontrol dan transisi dari keadaan tidak berdaya. Dalam pandangan Elisheva Sadan (2004, p. 137), pemberdayaan masyarakat tingkat makro adalah proses sosial secara kolektif untuk mencapai kontrol dan pengambilan keputusan yang lebih baik terhadap lingkungan dan kelompok atau partisipasi masyarakat. Artinya, pemberdayaan itu berkaitan dengan proses memberdayakan sosial menuju lebih baik.

Pemberdayaan juga sebagai langkah untuk mengatasi masalah sosial yang lebih luas dalam jangka panjang, seperti status ekonomi, pendidikan, kesehatan dan hak asasi (Anme, 2008, p. 10). Adapun pemberdayaan yang diawali oleh gagasan Paulo Freire mencatat tiga komponen penting dalam pemberdayaan masyarakat agar efektif, yaitu pendidikan, organisasi, dan jejaring (Anme, 2008, p. 11). Selain gagasan Paulo Freire itu, terdapat empat jenis pemberdayaan, yakni; 1) pertimbangan efektif dan refleksi moral; 2) pemberdayaan sebagai proses pribadi; 3) pemberdayaan sebagai aktivitas politik dan proses sosial; dan (4) pemberdayaan sebagai keseimbangan dan saling ketergantungan (Anme, 2008, p. 13).

Pada intinya, pemberdayaan merupakan bagian dari paradigma pembangunan. Fokus perhatiannya adalah semua aspek yang paling mendasar dari manusia di lingkungan hidupnya, mulai aspek intelektual, material dan fisik, hingga aspek manajerial (Rahayu, 2006). Aspek tersebut dapat dikembangkan oleh berbagai pihak dalam upaya peningkatan kuantitas dan kualitas hidup, seperti peningkatan pendapatan ekonomi masyarakat. Dari sini dipahami bahwa pemberdayaan masyarakat dapat berperan untuk meningkatkan kualitas sumber daya manusia (SDM) terutama dalam membentuk dan mengubah perilaku masyarakat. Sehingga masyarakat pada umumnya mencapai taraf hidup yang lebih berkualitas.

Pemberdayaan lebih spesifik fokusnya pada pedagan kecil. Pedang kecil menurut Saputra (2014) adalah kelompok tenaga kerja mandiri di sektor informal yang rata-rata memiliki penghasilan 1.500.000-2.500.000. Usaha mandiri tersebut biasanya tidak memiliki SIUP tetapi masyarakat hanya cukup melaporkan baik terhadap kelurahan untuk toko-toko maupun yang bertanggung jawab jika berada disepanjang jalan atau trotoar (Duwit et al, 2015). 


\section{METODE}

Metode yang digunakan dalam penelitian ini adalah deskriptif-eksplanatif. Penelitian deskriptif merupakan metode dalam meneliti suatu kondisi, suatu objek dan peristiwa yang terjadi (Nazir, 1998, p. 63), Penelitian deskriptif memiliki tujuan menggambarkan secara cermat suatu fenomena (Adi, 2004, p. 72). yang dalam penelitian ini akan menjelaskan kebijakan pemerintah yang melarang pembangunan ritel modern di Kabupaten Banyuwangi.

Sementara eksplanatif menjawab tentang mengapa kondisi itu terjadi, yang berupaya mengungkap alasan-alasan pemerintah melakukan kebijakan larangan pembangunan ritel modern dan dampak dari kebijakan tersebut. Penelitian ini bersifat literer, yaitu dengan menggunakan tinjauan pustaka, dokumen dan bahan-bahan tertulis lainnya yang memiliki keterkaitan dengan tema penelitian (Anwar, 1996, p. 135). Adapun fokus penelitian ini adalah mengkaji kebijakan yang diambil oleh Pemerintah Kabupaten Banyuwangi yang melarang pembangunan mal dan ritel modern. Untuk mengungkap secara gamblang kebijakan tersebut, maka digunakan data sekunder yang diambil dari situs-situs resmi pemerintah maupun nonpemerintah, media massa, publikasi jurnal ilmiah, artikel dan buku-buku terkait.

\section{Hasil dan Pembahasan}

\section{A. Kebijakan Larangan Pembangunan Mall dan Ritel Modern di Banyuwangi}

Pemerintah Kabupaten Banyuwangi bersama dengan Dewan Perwakilan Rakyat daerah (DPRD) mengeluarkan kebijakan yang melarang pendirian bangunan mall dan ritel modern di Banyuwangi. Larangan kebijakan itu diatur dalam Peraturan Daerah (Perda) Kabupaten Banyuwangi Nomor. 11 tahun 2014 tentang ketertiban umum dan ketenteraman masyarakat di Kabupaten Banyuwangi. Dalam Perda tersebut, pasal 26 poin (a) berbunyi "Setiap orang/badan dilarang mendirikan dan melakukan usaha baru berupa tempat hiburan karaoke dan usaha toko modern." Dengan perda ini, pemerintah daerah memiliki kekuatan dalam upaya mempertahankan pasar rakyat tidak tergerus zaman. Perda ini merupakan terobosan baru dan pertama kali lahir di Indonesia. Pasalnya, selama ini belum ada kabupaten/kota yang memiliki Perda larangan pembangunan mall (Akmal, 2016). Selain itu, langkah yang dapat mempersempit ruang gerak pasar modern ini tidak mudah diubah oleh pejabat pemerintah setelahnya.

Kebijakan Pemerintah Kabupaten Banyuwangi dengan menerbitkan larangan pembangunan pasar modern menjadi perhatian khusus karena tujuannya ingin menertibkan ruang bagi ekonomi masyarakat serta memberikan kenyamanan bagi sistem pasar lokal dengan menekan tumbuh suburnya pasar modern. Adapun maksud pasar modern yang tidak mendapat izin pembangunan di Banyuwangi mengacu pada Peraturan Presiden (perpres) No. 112 tahun 2007. Dalam Perpres tersebut, pada pasal 1 poin (5) dijelaskan bahwa pasar modern adalah toko dengan sistem pelayanan mandiri, menjual berbagai jenis barang secara eceran yang berbentuk Minimarket, Supermarket, Department Store, Hypermarket ataupun grosir yang berbentuk Perkulakan. Begitu pun pasal 3 poin (3) juga mengatur mengenai sistem penjualan dan jenis barang dagangan dalam toko modern. Setidaknya ada 3 poin yang harus dipahami, yaitu; pertama, Minimarket, Supermarket dan Hypermarket menjual secara eceran barang konsumsi terutama produk makanan dan produk rumah tangga lainnya. Kedua, Departemen Store menjual secara eceran barang konsumsi utamanya produk sandang dan perlengkapannya dengan penataan barang berdasarkan jenis kelamin dan/atau tingkat usia konsumen. Ketiga, perkulakan menjual secara grosir barang konsumsi.

Azwar Anas selaku Bupati Banyuwangi mengatakan bahwa di antara toko modern yang tidak mendapat izin pembangunan di Banyuwangi adalah Indomart dan Alfamart. Dia mengatakan bahwa Pemkab Banyuwangi anti terhadap Alfamart dan anti-Indomart, apalagi pasar modern itu dibangun di wilayah perkotaan (Mustholih, 2014). Kebijakan lainnya juga berlaku terhadap ritel modern yang tidak berjaringan. Bagi pria yang menjabat selama dua periode sebagai Bupati Banyuwangi itu, keberadaan mal tidak menggambarkan kondisi ekonomi masyarakat daerah, tetapi hanya sebuah gaya hidup. Selain itu, keberadaan mal sebatas prestise perilaku yang tidak berkontribusi pada ekonomi masyarakat (Reviati, 2016).

Kebijakan yang melarang pembangunan mal di daerah tersebut tidak lantas di Banyuwangi tidak ada ritel modern sama sekali. Setidaknya ada tujuh ritel modern yang berada di pusat keramaian Kabupaten Banyuwangi. Di antara ritel modern tersebut adalah sebagai berikut:

Tabel 1.

Daftar Beberapa Ritel Modern di Banyuwangi

\begin{tabular}{lll}
\hline No. & \multicolumn{1}{c}{ Nama } & \multicolumn{1}{c}{ Alamat } \\
\hline 1 & Supermarket X & Banyuwangi \\
\hline 2 & Roxy Mall & $\begin{array}{l}\text { Jl. Jendral Sudirman, Pengan- } \\
\text { juran, Banyuwangi }\end{array}$ \\
\hline 3 & Ramayana & $\begin{array}{l}\text { Jl. Adi Sucipto, Tukangkayu, } \\
\text { Banyuwangi }\end{array}$ \\
\hline 4 & Vionata swalayan & $\begin{array}{l}\text { Jl. Jendral Ahmad Yani, Tu- } \\
\text { kangkayu }\end{array}$ \\
\hline
\end{tabular}




\begin{tabular}{cll}
\hline 5 & Mitra swalayan & Jl. Yos Sudarso, Gambiran, \\
\hline 6 & Sun East Mall & $\begin{array}{l}\text { Jl. Diponegoro, Genteng, } \\
\text { Banyuwangi }\end{array}$ \\
\hline 7 & Barokah Toserba & $\begin{array}{l}\text { Jl. Seneporejo, Bangorejo, } \\
\text { Banyuwangi }\end{array}$ \\
\hline
\end{tabular}

Sumber: Laporan Penelitian Gustra Gilang tahun 2018

Berdasarkan tabel tersebut, diketahui bahwa di Kabupaten Banyuwangi masih ada ritel modern meskipun sudah diterbitkan peraturan daerah mengenai larangan pembangunan pasar modern di Banyuwangi. Mengenai hal tersebut, bupati Banyuwangi menjelaskan bahwa Perda tersebut berlakubagipembangunan baru ritel modern, namun tidak berlaku bagi ritel yang terlanjur mendapat izin pembangunan dari pejabat pemerintah daerah sebelumnya. Pihaknya juga mengatakan bahwa dalam perkembangannya masih banyak sekali para pemilik modal yang berminat membangun mal di Banyuwangi, tetapi dia menegaskan bahwa Banyuwangi tidak membutuhkan investasi mal dan ritel modern (Reviati, 2016).

Pemkab Banyuwangi secara konsisten memproteksi keberadaan usaha kecil atau pasar tradisional dengan cara melarang berdirinya pasar modern di Banyuwangi terutama di dekat pasar tradisional (Albab, 2016). Langkah mempersempit ruang gerak pasar modern ini bermaksud memberdayakan pedagang lokal, sehingga pasar tradisional di Banyuwangi tidak menjadi sebatas sejarah, namun tetap eksis di tengah arus globalisasi. Terkait ritel modern yang dibiarkan tetap beroperasi, Yusuf Widyatmoko selaku Wakil Bupati Banyuwangi menjelaskan bahwa pemerintah daerah saat ini tidak bisa serta merta mencabut izin operasi ritel modern, karena bisa dituntut secara hukum dan menimbulkan ketidakpastian iklim usaha (Banyuwangi, 2017).

Bagi mal dan ritel modern yang terlanjur berdiri, pemerintah setempat mengontrol keberadaannya dan jangka waktu izinnya. Apabila diketahui tidak memiliki izin, maka dengan tegas Pemkab Banyuwangi membubarkan ritel modern tersebut. Pada tahun awal diberlakukannya kebijakan penertiban umum, Pemerintah Kabupaten Banyuwangi yang dipimpin oleh Azwar Anas itu telah membubarkan sebanyak 12 Indomart dan Alfamart yang tidak mengantongi izin dari pemerintah daerah setempat (Zul, 2012). Penutupan minimarket yang tak berizin merupakan hal yang lumrah dilakukan oleh pemerintah di berbagai daerah, tetapi Pemkab Banyuwangi tidak membiarkan ruang perpanjangan atau buka kembali bagi minimarket yang tidak berizin.

Pemkab Banyuwangi juga membatasi jam operasional bagi ritel modern yang sudah ada. Jam operasional ritel modern maksimal 17 jam per hari-tidak ada ritel yang buka selama 24 jam per hari. Bahkan, antara eksekutif dan legislatif dalam hal ini satu suara dengan mengatakan "haram" hukumnya bagi ritel modern yang beroperasi selama 24 jam per hari (Arifin, 2016). Operasional jam buka ritel modern berbeda-beda antara yang ada di wilayah perkotaan dan di wilayah pinggiran. Bagi ritel yang berdiri di wilayah perkotaan diberikan jam buka mulai dari pukul 10.00 WIB sampai 03.00 WIB. Sedangkan yang terletak di wilayah pinggiran jam operasionalnya mulai pukul 10.00 WIB hingga jam 00.00 (Arifin, 2016). Di Kabupaten Banyuwangi pembatasan jam operasional selama 17 jam per hari itu berlaku bagi toko modern yang tidak berjaringan, seperti supermarket, hypermarket dan pusat perbelanjaan modern lainnya (Radar, 2016).

Kebijakan Pemerintah Kabupaten Banyuwangi yang melarang pembangunan ritel modern mendapatkan apresiasi dari mantan Mentri Perdangan, Enggartiasto Lukita. Enggartiasto yang menjabat sebagai Menteri Perdagangan Indonesia mulai 2016 hingga 2019, mengatakan bahwa Banyuwangi sudah mulai melakukan pembangunan yang berkeadilan dengan diawasinya ritel modern. Menurutnya, pembatasan itu tentunya untuk melindungi pedagang-pedagang kecil sehingga mereka tidak tergerus zaman (Radar, 2016).

Kebijakan seperti ini dapat menjadi contoh bagi pemerintah daerah lainnya. Kebijakan ini dapat diterapkan untuk menekan menjamurnya ritel modern di berbagai daerah di Indonesia. Dengan dukungan pemerintah pusat, larangan izin ritel modern dapat meningkatkan ekonomi mikro masyarakat. Pemerintah pusat melalui Kementerian Perdagangan dapat mendukung kebijakan ini untuk pemberdayaan pedagang kecil (Radar, 2016). Harapannya, pedang kecil dapat memiliki akses dan harga yang sama seperti pasar modern. Pedagang kecil juga dapat memiliki kredit perbankan dengan mudah, sehingga pedagang kecil dapat meningkatkan model kerja serta berinovasi untuk pengembangan ekonominya.

Dalam analisis kebijakan publik, munculnya kebijakan ini sebagai upaya untuk melayani kepentingan publik. Bentuk memenuhi kepentingan publik dengan memberdayakan ekonomi masyarakat kecil dan mengatur pasar dengan tidak adanya penerbitan izin untuk pembangunan ritel modern. Dengan kebijakan dan pemberdayaan ini, masyarakat tidak akan terasingkan dari daerahnya sendiri. sehingga ekonomi masyarakat secara merata berpotensi lebih berkembang daripada kebijakan pemerintah daerah yang membiarkan ritel modern menjamur di suatu daerah. Hal ini menunjukkan bahwa pemerintah daerah merumuskan dan menerapkan suatu kebijakan untuk memenuhi segala kebutuhan masyarakatnya sendiri. 


\section{B. Pemberdayaan Ekonomi Pedagang Kecil}

Kebijakan larangan pembangunan mal dan ritel modern merupakan bentuk dari pemberdayaan ekonomi masyarakat. Yusuf Widyatmoko mengatakan larangan pendirian mal merupakan kebijakan strategis di bidang perdagangan yang pro-usaha kecil. Kebijakan penertiban umum itu diluncurkan untuk melindungi usaha mikro yang bergerak di sektor perdagangan (Banyuwangi, 2017). Pemkab Banyuwangi-dalam hal ini Dinas Perdagangan-melakukan penertiban sistem ekonomi dan pembinaan terhadap pedang kecil agar tetap eksis di tengah persaingan pasar modern.

Pedagang kecil tidak bisa dibiarkan bertarung bebas dalam dinamika ekonomi, tapi pemerintah harus hadir melindungi dengan kebijakan dan pembinaannya. Bukan hal yang tidak mungkin pedang kecil akan kalah bersaing dengan toko modern yang tidak hanya dilengkapi dengan kelengkapan kebutuhan yang dibutuhkan masyarakat, tetapi model layanan yang nyaman, dan fasilitas yang sangat lengkap. Dengan demikian, jika pemerintah membiarkan secara terbuka terhadap pembangunan ritel modern, maka pedagang kecil semakin hari semakin hilang kekuatannya, kemudian akan lenyap dari kelangsungan hidup masyarakat.

Setidaknya, ada tiga paradigma yang berbeda untuk melihat persoalan-persoalan yang dihadapi pedagang kecil. Ketiga paradigma itu adalah paradigma modernisasi, paradigma liberal, dan paradigma transformatif. Dalam paradigma modernisasi, gagasan utamanya terletak pada akar persoalan yang dihadapi masyarakat. Paradigma ini melihat bahwa tatanan sosial merupakan konsensus yang baik, tidak dipermasalahkan sehingga layak dipertahankan (Mulyanto, 2006, p. 3). Jika menggunakan paradigma ini dalam memandang persoalan yang dihadapi oleh pedagang kecil di Banyuwangi, maka ditemukan bahwa persoalannya terletak pada keterbelakangan budaya, kebodohan, dan kemiskinan absolut yang tertanam dalam diri pelaku usaha. Untuk memecahkan persoalan tersebut, paradigma modernisasi menawarkan untuk mengubah nilai dan norma tradisional yang berkenaan dengan usaha. Aktor utama untuk mencapai perubahan adalah pemerintah dan lembaga-lembaga bantuan dengan kepemimpinan yang birokratis (Mulyanto, 2006, p. 3).

Adapun paradigma liberal ada sedikit persamaan dengan paradigma modernisasi dalam memandang persoalan yang dihadapi masyarakat. Paradigma liberal melihat tatanan sosial-ekonomi sebagai konsensus. Meski demikian, tatanan sosial tersebut tidak berfungsi sebagaimana mestinya, ada sejumlah hambatan yang mengganggu kelangsungan tatanan sosial. Paradigma ini memandang bahwa peran pemerintah kurang terbuka dan kurang memberi kesempatan kepada semua pihak dalam berusaha (Mulyanto, 2006, p. 4). Berdasarkan paradigma liberal ini, solusi terpenting untuk mengatasi persoalan yang dihadapi pedagang kecil adalah perubahan kebijakan Pemerintah Kabupaten Banyuwangi dengan membuka kesempatan dan akses seluas-luasnya kepada pedagang kecil. Dalam hal ini, pemerintah daerah juga bisa memberikan program pelatihan manajerial, memberikan pinjaman modal, kemudian membantu dalam pemasaran barang yang dikelola oleh pedagang kecil di daerah tersebut.

Sedangkan paradigma transformatif jauh lebih dalam melihat persoalan di atas. Paradigma transformatif memandang bahwa terdapat ketidakadilan dalam tatanan sosial-ekonomi. Struktur sosial tempat pelaku usaha kecil berada merupakan hasil pemaksaan dari sebagian kelas masyarakat (Mulyanto, 2006, p. 4). Jika menggunakan paradigma transformatif ini untuk melihat persoalan pedagang kecil di Banyuwangi, maka tampak bahwa akar persoalannya terletak pada struktur sosial dan segala hubungan di dalamnya tidak adil. Persoalan tersebut bisa dipecahkan hanya melalui perubahan sistem atau penataan kembali struktur sosial sehingga lahir struktur baru yang lebih adil. Dengan menggunakan paradigma ini, perubahan bisa dicapai bukan hanya bergantung pada pemerintah, melainkan masyarakat sendiri dipercaya dapat melakukan perubahan.

Dari tiga paradigma di atas, tampak banyak perubahan yang terjadi di Kabupaten Banyuwangi, baik perubahan yang dilakukan oleh pemerintah maupun oleh masyarakat itu sendiri. Salah satu perubahan besar yang ditunjukkan oleh Pemerintah Kabupaten Banyuwangi adalah lahirnya kebijakan penertiban toko modern. Kebijakan ini terbukti berdampak pada perubahan masyarakat, misalnya pada pemerintahannya sebelumnya sudah terlanjur memberi izin pembangunan ritel modern sehingga pedagang kecil mulai tersisihkan, tapi setelah adanya laranya pembangunan ritel modern menunjukkan pertumbuhan atau peningkatan kuantitas dan kualitas pedagang kecil, pertokoan dan pasar tradisional.

Berdasarkan data statistik Kabupaten Banyuwangi pada tahun 2014 bahwa perusahaanperusahaan yang memiliki surat izin usaha (SIUP) menurut klasifikasi golongan yaitu tercatat ada sebanyak 1.302 pedagang/perusahaan kecil, sebanyak 25 pedagang/perusahan sedang dan 3 pedagang besar yang tersebar di seluruh wilayah Kecamatan Banyuwangi (BPS, Banyuwangi dalam Angka Tahun 2014, 2014, hal. 178). Sedangankan untuk pedangan-pedangan kecil yang tidak masuk 
pada SIPUP yaitu pada tahun 2015, jumlah pelaku UMKM di seluruh Banyuwangi sebanyak 269,267 dari total sekitar 1,6 juta jiwa penduduk. Para pelaku usaha sebesar 90 persen didominasi pelaku usaha mikro dan kecil, sedangkan sebesar 10 persen merupakan usaha menengah. Jumlah tersebut meningkat jika dibandingkan dengan tahun-tahun sebelumnya, apalagi tahun 2011 yang hanya berkisar pada 131.000 pelaku usaha (Kumparan, 2017). Sedangkan pada tahun 2017, keberadaan pedagang kecil lebih terperinci dan jumlahnya lebih besar, yaitu terdapat 111 pasar dan sebanyak 16.616 pertokoan di wilayah Banyuwangi (BPS, 2017).

Data statistik ini menunjukkan bahwa pedagang kecil dapat tumbuh dan berkembang di Banyuwangi. Pertumbuhan itu secara tidak langsung karena kebijakan pemerintah yang mempersempit ruang gerak pasar modern (Fanani, 2017). Pemkab setempat menyadari bahwa menjamurnya beberapa ritel modern di daerah-daerah berdampak pada penghasilan dan keberadaan pedagang kecil. Hal ini dapat dilihat di beberapa kabupaten, seperti Jember dan Malang yang memberikan ruang terbuka bagi pembangunan ritel modern. Dari dua kabupaten tersebut tampak ancaman nyata dari keberadaan ritel modern, di antaranya: pertama, mematikan penjual di pasar tradisional karena adanya pergeseran kebiasaan konsumen. Dikabupaten Jember terjadi penurunan omzet pedagang kecil rata-rata 50\%-70\% (Meikyansyah, 2019).

Kedua, terkait permasalahan perekonomian lokal. Awalnya, perputaran uang di daerah sebagian besar merupakan kontribusi dari Usaha Kecil Menengah (UKM), tetapi seiring dengan berkurangnya UKM dan pasar tradisional akibat kalah bersaing dengan pasar modern, maka secara otomatis mengecilkan kontribusinya terhadap perekonomian lokal. Keberadaan pasar modern di suatu daerah tidak memberikan sumbangan yang signifikan pada perekonomian lokal, karena pendapatan yang diperoleh dari pasar modern biasanya hanya berasal dari pajak IMB dan pajak reklame (Sarwoko, 2008, p. 101).

Selain melarang pembangunan ritel modern, Pemerintah Kabupaten Banyuwangi melakukan dua hal dalam mengembangkan pedagang kecil, yaitu keuangan dan non-keuangan. Pendekatan keuangan dilakukan untuk mendukun pembiayaan pedagang kecil, baik melalui dana bergulir maupun perbankan. Sedangkan non-keuangan dilakukan dengan pelatihan dan pendampingan mulai dari manajemen keuangan, manajemen pemasaran dan diversifikasi produk, termasuk pendampingan untuk menciptakan nilai tambah produk, seperti UMKM perikanan di Banyuwangi yang bisa memiliki produk bakso ikan (Kumparan, 2017).

Di samping itu, Pemkab Banyuwangi juga memfasilitasi usaha mikro, kecil dan menengah
(UMKM) dalam pengurusan hak merek, sertifikat halal, dan uji laboratorium standarisasi. Pemerintah juga mendampinginya melalui promosi dan pemasaran produk UMKM dengan meluncurkan Banyuwangi-mall.com, sebuah situs belanja online khusus berisi produk-produk UMKM Banyuwangi (Kumparan, 2017). Situs tersebut sebagai bentuk sistem pemasaran modern melalui $e$-commerce yang bertujuan untuk mengangkat pendapatan lokal. E-commerce Banyuwangi Mall ini telah mewadahi 10.000 UMKM yang tidak memiliki modal untuk membuka toko sendiri (Reviati, 2016).

Pemerintah juga membekali masyarakat dengan pelatihan-pelatihan internet yang secara spesifik mempelajari sistem pemasaran. Pada tahun 2016, Pemkab Banyuwangi telah melakukan pelatihan internet marketing untuk anak muda sebagai salah satu cara techno-preneurship yang diikuti sebanyak 2.000 peserta (Reviati, 2016). Tekhno-preunership adalah salah satu cara dan bekal pendidikan untuk anak-anak Banyuwangi untuk memasarkan produk-produk lokal dengan sistem teknologi. Dalam hal ini, Bupati Banyuwangi, Anas mengatakan bahwa di era globalisasi, penggunaan TI sebagai cara strategis menguatkan UMKM untuk dapat berdaya saing. Dengan TI pangsa pasar dapat meluas dan lebih menguntungkan, antara pedagang dan pembeli bisa bertransaksi langsung tanpa pihak ketiga, sehingga keuntungan yang didapat bisa lebih tinggi (Banyuwangi, 2017).

Penggunaan TI adalah keniscayaan untuk meningkatkan daya saing dalam sektor ekonomi. Pemerintah Kabupaten Banyuwangi melalui Dinas Koperasi (Diskop) juga melakukan inovasi pada UMKM, seperti Marketing Online (MOL) untuk memfasilitasi promosi produk, menyediakan wadah pasar digital dengan situs www.banyuwangi-mall. com, fasilitas Report Online (ROL) untuk percepatan pelaporan perkembangan pengelolaan keuangan koperasi, serta optimalisasi pelayanan Klinik $\mathrm{K}$-UMKM baik berupa in the office maupun mobile (Banyuwangi, 2017).

Pemerintah Kabupaten Banyuwangi terus mendorong UMKM berkembang dan tidak khawatir ketika harus bersaing dalam Masyarakat Ekonomi Asean (MEA) yang mulai diterapkan awal tahun 2015. Pemkab setempat percaya bahwa ke depannya UMKM Banyuwangi dapat diminati oleh masyarakat luas. Selain itu, pemerintah setempat mendorong pemuda untuk melek teknologi terutama terkait dengan e-commerce. Dengan pembangunan yang pro terhadap rakyat kecil ini, Muhammad Erfan Agustian menilai UMKM, pasar tradisional dan pedagang kaki lima diberikan pelayanan dan kesempatan yang luar biasa besar untuk berkembang di Banyuwangi. Pemerintah juga mendukung pemuda untuk menjadi entrepreneur dari sektor ekonomi kreatif (Kurniawan, 2017). Langkah Pemkab Banyuwangi 
tersebut sangat membantu pertumbuhan ekonomi dan indeks kesejahteraan masyarakat.

Langkah Pemkab Banyuwangi juga inheren dengan pertumbuhan ekonomi dan pengurangan angka kemiskinan. Pertumbuhan ekonomi Banyuwangi menunjukkan lebih tinggi dari pertumbuhan rata-rata ekonomi Jawa Timur dan nasional per 2010-2014. Rata-rata pertumbuhan ekonomi Kabupaten Banyuwangi dari 2010-2014 sebesar 6,59 persen (Wirawan, 2016). Pendapatan per kapita penduduk dari Rp14,7 juta per orang (per tahun) meningkat menjadi Rp33,7 juta per orang di tahun 2015 (Wirawan, 2016). Tidak hanya berhenti di angka itu, meskipun tanpa mal, namun pendapatan per kapita terus naik, terlihat pada tahun 2019 mencapai Rp48 juta per orang (viva.co.id 2019). Income per kapita Banyuwangi menyalip kota-kota besar lainnya di provinsi Jawa Timur dan nasional. Berikut ini tabel pertumbuhan ekonomi Kabupaten Banyuwangi dari tahun 2010 hingga 2019.

Peningkatan ekonomi masyarakat juga terkonfirmasi melalui kinerja perbankan. Berdasarkan data resmi Bank Indonesia (BI), penyaluran kredit masyarakat di Banyuwangi pada 2010 sebesar Rp3,29 triliun, pada tahun 2015 terjadi pertumbuhan sebesar 5,64 triliun. Terhitung pada November 2015, kredit usaha masyarakat mencapai 8,93 triliun. Secara kumulatif tumbuh 171,43 persen atau rata-rata 34,82 persen per tahun (Banyuwangi, 2016). Indikator angka kredit masyarakat ini menunjukkan bahwa perekonomian Banyuwangi membaik sehingga debitur lancar dalam menunaikan kewajiban kreditnya (Banyuwangi, 2016). Selain itu, indikator tersebut menunjukkan terjadinya perputaran kredit yang sehat bagi dunia usaha masyarakat kecil di Kabupaten Banyuwangi.

Dalam rangkaian pemberdayaan pedagang kecil atau pasar tradisional, Pemerintah Kabupaten Banyuwangi meluncurkan sistem pembayaran retribusi berbasis elektronik atau e-retribusi. Sistem e-retribusi ini merupakan pertama kali di Indonesia. Dalam hal ini, Pemkab Banyuwangi menggandeng PT BNI Tbk, dan PT Bank Jatim Tbk. Sistem e-retribusi setidaknya memiliki tiga tujuan, yaitu; pertama, sebagai komitmen pemerintah untuk meningkatkan transparansi dalam pengelolaan daerah. Di sini pemerintah tidak memberikan ruang bagi petugas untuk menyelewengkan penggunaan retribusi. Harapan diluncurkannya e-retribusi ini dapat meningkatkan kepercayaan masyarakat terhadap pemerintah. Kedua, memudahkan pedagang dalam membayar retribusi serta masyarakat dituntun untuk melek teknologi. Ketiga, masyarakat memiliki buku tabungan di bank yang tidak hanya dapat digunakan untuk e-retribusi, tetapi simpanan dan kemudahan pinjaman di bank (Akmal, 2017). Bahkan, pemerintah menekankan kepada mitra kerja untuk selalu memudahkan pedagang kecil melakukan pinjaman, sehingga ke depan usahanya semakin berkembang.

Selain pertumbuhan ekonomi, berbanding lurus juga dengan menurunnya angka kemiskinan yang cukup signifikan. Angka kemiskinan Kabupaten Banyuwangi pada tahun 2010 mencapai 40 persen, menurun drastis selama lima tahun menjadi 9,3 persen di tahun 2015 (Akmal, 2016). Bahkan pada tahun 2019, BPS Kabupaten Banyuwangi merilis angka kemiskinan di Banyuwangi 2019 menjadi 7,52 persen (BPS, 2020). Hal ini merupakan implikasi nyata dari adanya kebijakan yang melarang pembangunan ritel modern. Peningkatan ekonomi dan pengurangan kemiskinan tidak terlepas dari upaya pemerintah daerah yang terus memproteksi pedagang lokal dan melarang ritel modern menjamur di Banyuwangi. Dengan kebijakan tersebut yang disertai dengan pemberdayaan menjadi salah satu kunci agar usaha para pedagang kecil tetap hidup.

\section{KESIMPULAN}

Kebijakan Pemerintah Kabupaten Banyuwangi melarang pembangunan mal dan ritel modern sebagai strategi memberdayakan pedagang kecil. Pemerintah ingin meningkatkan pertumbuhan ekonomi dan pengurangan kemiskinan melalui inovasi UMKM untuk dapat berdaya saing dengan memasarkan produknya melalui sistem e-commerce. Kebijakan larangan pembangunan ritel model pada

Tabel 2.

Pertumbuhan Ekonomi Kabupaten Banyuwangi

\begin{tabular}{|c|c|c|c|c|c|c|c|c|c|c|c|}
\hline \multirow[b]{2}{*}{ NO. } & \multirow[b]{2}{*}{ KETERANGAN } & \multirow[b]{2}{*}{2010} & \multirow[b]{2}{*}{2011} & \multirow[b]{2}{*}{2012} & \multicolumn{7}{|c|}{ TAHUN } \\
\hline & & & & & 2013 & 2014 & 2015 & 2016 & 2017 & 2018 & $2019 *$ \\
\hline 1 & $\begin{array}{l}\text { Kab. } \\
\text { Banyuwangi }\end{array}$ & 6.38 & 6.95 & 7.24 & 6.71 & 5.91 & 6.01 & 5.38 & 5.60 & 5.84 & 5.71 \\
\hline 2 & Jatim & 6.31 & 6.44 & 6.64 & 6.08 & 5.86 & 5.49 & 5.55 & 5.72 & 5.65 & \\
\hline 3 & Nasional & 6.10 & 6.50 & 6.23 & 5.78 & 5.02 & 4.79 & 5.02 & 5.06 & 5.17 & \\
\hline
\end{tabular}

Sumber: BPS Pemkab Banyuwangi 2019 
suatu daerah terbukti dapat meningkatkan ekonomi masyarakat dan secara signifikan melepaskan masyarakat dari jerat kemiskinan.

\section{UCAPAN TERIMA KASIH}

Atas terselesainya artikel ini, kami mengucapkan terimakasih kepada Kepala Badan perencanaan dan pembangunan daerah, informan penelitian, teman-teman dilingkungan fakultas ilmu social dan ilmu politik sebagai sharing diskusi research, dan Rachmat Hidayat, Ph.D yang banyak memberikan masukan dan kritikan dalam terselesainya artikel ini. Semoga artikel ini dapat memperkaya referensi dalam dunia akademik dan perumusan kebijakan.

\section{Daftar Pustaka}

Adi. (2004). Metodologi Penelitian Sosial dan Hukum. Jakarta: Granit.

Akmal, P. (2016). Ini Upaya Bupati Anas Proteksi Pasar Tradisional di Banyuwangi. https://news. detik.com/berita-jawa-timur/d-3275639/iniupaya-bupati-anas-proteksi-pasar-tradisionaldi-banyuwangi

Akmal, P. (2017). Pemkab dan BNI Luncurkan e-Retribusi di Pasar Banyuwangi. https://news. detik.com/berita-jawa-timur/d-3699102/ pemkab-dan-bni-luncurkan-e-retribusi-dipasar-banyuwangi

Albab, M. U. (2016). Selama BEC, PKL Diizinkan Berjualan di Atas Trotoar Jalan. https:// banyuwangi.merdeka.com / pariwisata/ selama-bec-pkl-diizinkan-berjualan-di-atastrotoar-jalan-1611122.html

Anme Tokie, M. M. (2008). Culture, Care, and Community Empowerment: International Applications of Theory and Methods. Tokyo: Kawashima Shoten Publisher.

Anwar, T. M. (1996). Menyususun Rencana Penelitian. Jakarta: Rajawali.

Arifin, S. (2016). Toko Modern di Banyuwangi 'Haram' Buka 24 Jam. https://www.timesindonesia. co.id/read/news/125552/toko-modern-dibanyuwangi-haram-buka-24-jam

banyuwangi.go.id. (2016). Pertumbuhan Ekonomi Dinilai Terbaik, Banyuwangi Peroleh Goverment Awards 2016. https://www.banyuwangikab. go.id/berita-daerah/pertumbuhan-ekonomidinilai-terbaik-banyuwangi-perolehgoverment-awards-2016.html

banyuwangi.go.id. (2017). Bank Indonesia Gelar Ajang Terpadu Dekatkan TI ke UMKM Banyuwangi. https://www.banyuwangikab. go.id/berita-daerah/bank-ind onesia-gelarajang-terpadu-dekatkan-ti-ke-umkmbanyuwangi.html banyuwangi.go.id. (2017). Mendag Apresiasi Kebijakan Banyuwangi Batasi Ritel Modern. https://www.banyuwangikab.go.id/beritadaerah / mendag-apresiasi-kebijakanbanyuwangi-batasi-ritel-modern.html

BPS. (2014). Banyuwangi dalam Angka Tahun 2014. Banyuwangi: BPS Banyuwangi.

BPS. (2017). Kabupaten Banyuwangi dalam Angka 2017. Banyuwangi: BPS Kabupaten Banyuwangi.

BPS. (2020, April 6). Sampaikan LKPJ Secara Virtual, Bupati Anas Sebut Kemiskinan Banyuwangi Turun 7,52 Persen.

detik.com. (2012, Mei 8). Larang Mal Berdiri, Bupati Banyuwangi 'Disemprot' Pengembang. https:// finance.detik.com/properti/d-1912243/ larang-mal-berdiri-bupati-banyuwangidisemprot-pengembang

Duwit. S.B, Kumurur. A.V, Moniaga. L. I, (2015). Persepsi pedagang kaki lima terhadap area berjualan sepanjang jalan pasar pinasungkulan Karombasan Manado. Sabua. Vol.7, no 2. https: //ejournal.unsrat.ac.id/index.php/ SABUA/article/view/9586

Fanani, Ardian. (2017). Banyuwangi batasai gerai ritel modern, ini kata menag. https:// finance.detik.com / berita-ekonomi bisnis/d-3537138/banyuwangi-batasi-gerairitel-modern-ini-kata-mendag

Haryotejo Bagas (2014). Dampak Ekspansi Hypermarket Terhadap Pasar Tradisional di Daerah. Jurnal Bina Praja. Vol. 6 No 3, hal. 237-248. https://doi.org/10.21787/ jbp.06.2014.241-248

Heung-Ryel, K. (2015). Culture and TourismOriented Local Traditional Market Strategies in Korea. Proceedings of the First European Academic Research Conference on Global Business, Economics, Finance andSocial Sciences (EAR15Italy Conference).

kumparan.com (2017). Strategi Tumbuh Kembang UMKM di Banyuwangi. https://kumparan.com/ rina-nurjanah/strategi-tumbuh-kembangumkm-di-banyuwangi/full

Kurniawan, A. (2017, Oktober 1). Keberpihakan Bupati Anas ke UMKM Diapresiasi. https:// daerah.sindonews.com/berita/1244511/23/ keberpihakan-bupati-anas-ke-umkmdiapresiasi

Mulyanto, D. (2006). Usaha Kecil dan Persoalannya di Indonesia. Bandung: Yayasan AKATIGA.

Mustholih. (2014). Indomaret \& Alfamart Diboikot di Banyuwangi. https://news.okezone.com/ $\mathrm{read} / 2014 / 03 / 01 / 521 / 948642 /$ indomaretalfamart-diboikot-di-banyuwangi

Meikyansyah C. (2019). Perlu ada zonasi ritel modern di Jember. https://mediaindonesia. 
com/read/detail/219235-perlu-ada-zonasiritel-modern-di-jember

Nazir, N. (1998). Metode Penelitian. Jakarta: Ghalia Indonesia.

Nugroho, R. (2014). Public Policy. Jakarta: PT. Elex Media Komputindo.

Osman, F. A. (2002). Public Policy Making: Theories and Their Implications in Developing Countrie. Asian Affairs, Vol. 24, No. 3.

Radar. (2016). Jam Operasional Toko Modern di Banyuwangi Maksimal $17 \mathrm{Jam}$. https://www. kabarbanyuwangi.info/jam-operasional-tokomodern-di-banyuwangi-maksimal-17-jam. html

Rahayu, M. A. (2006). Pembangunan Perekonomian Nasional Melalui Pemberdayaan Masyarakat Desa. Diambil kembali dari Iskandar Institute: infodiknas.com

Reardon, B. J. (2002). "The Rapid Rise of Supermarkets in Latin America: Challenges and Opportunities for Development. Development Policy Review, 20. https://doi. org/10.1111/1467-7679.00178

Reinarts Werner, B. D. (2011). Retailing Innovation in a Globalizing Retail Market Environment. ELSEVIER. https://doi.org/10.1016/j. jretai.2011.04.009

Reviati, T. D. (2016, Maret19). Mal TakBoleh Didirikan di Banyuwangi, Ini Alasan Utamanya. https:// surabaya.tribunnews.com/2016/03/19/maltak-boleh-didirikan-di-banyuwangi-ini-alasanutamanya

Sadan, E. (2004). Empowerment and Community Planning: Theory and Practice of PeopleFocusedSocial Solutions. Tel Aviv: Hakibbutz Hameuchad Publishers. http://dx.doi. org/10.4236/ojpsych.2017.71002

Saputra, R.B. (2014). Profil Pedagang kaki lima yang berjualan di badan jalan. Jurnal: Jom FISIP. Vol. 1, No. 2. https://jom.unri.ac.id/index.php/ JOMFSIP/article/view/3122

Sarwoko, E. (2008). Dampak Keberadaan Pasar Modern terhadap Kinerja Pedagang Pasar Tradisional di Wilayah Kabupaten Malang. Jurnal Ekonomi Modernisasi, Vol. 4, No. 2. http://ejournal.unikama.ac.id/index.php/ JEKO/article/view/880
Setyorini, T. (2013). Kebijakan Pemkab Bantul dalam Menangani Menjamurnya Toko Modern. Jurnal PMI, Vol. X, No. 2. https://www.aifisdigilib.com/uploads/1/3/4/6/13465004/ jurnal_pmi_hlm_79_92.pdf

Soliha, E. (2008). Analisis Industri Ritel di Indonesia. Jurnal Bisnis dan Ekonomi (JBE), Vol. 15, No. 2. https://media.neliti.com/media/ publications/24251-ID-analisis-industri-riteldi-indonesia.pdf

Susilowati, K. D. (2014). The Impacts of Modern Market to traditional traders (A Case in Malang City - Indonesia). International Journal of Technical Research and Applications, Volume-2, Special Issue 8 .

Toma, E. F. (2014). Public Choice and Public Policy: A Tribute to James Buchanan. Southern Economic Journal, Vol. 80, No. 4. https://www.jstor.org/ stable/23807671

Triawan, A (2018). Analisis pengaruh toko ritel modern terhadap pendapatan pedagang tradisional dalam perspektif ekonomi islam. Falah: Jurnal Ekonomi Syari'ah. Vol. 3, No. 1. https://doi.org/10.4284/0038-40382013.306

viva.co.id (2019). Tanpa Mall, Pendapatan per Kapita Banyuwangi Rp48 Juta. Diambil kembali dari https://www.viva.co.id/berita/ bisnis/1191067-tanpa-mall-pendapatan-perkapita-banyuwangi-rp48-juta

Winarno, B. (2007). Kebijakan Publik: Teori dan Proses. Yogyakarta: Media Presindo.

Winarno, B. (2008). Globalisasi: Peluang atau Ancaman bagi Indonesia. Jakarta: Penerbit Erlangga.

Wirawan, O. A. (2016). Pemkab Banyuwangi Larang Ritel, Turunkan Angka Kemiskinan. http://m. beritajatim.com/ekonomi/260855/pemkab_ banyuwangi_larang_ritel,_turunkan_angka_ kemiskinan.html

Zul. (2012). Tutup 12 Minimarket, Bupati Banyuwangi Juga 'Haramkan' Mal. https:// finance.detik.com/properti/1911439/tutup12-minimarket-bupati-banyuwangi-jugaharamkan-mal- 